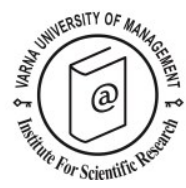

\title{
A confirmation of the four-component structure of destination image, and their relationships with tourists' loyalty
}

\author{
Bình Nghiêm-Phú ${ }^{1 *}$
}

Received: 13/10/2014 Accepted: 27/01/2015

\footnotetext{
${ }^{1}$ Graduate School of Media and Governance, Keio University; 5322 Endo, Fujisawa-shi, Kanagawa Prefecture, Japan 252-0882; tel: +81-80-3349-6176; e-mail: binhnghiem@z8.keio.jp

* Corresponding author
}

\begin{abstract}
Within the study on destination image, one of the issues remain unsatisfactorily addressed is the structure of the construct. Based on the existing literature, this study retests the cognitive-affective structure of destination image, with the cognitive component constructed by the tangible (functional), intangible (psychological), and mixed attributes. In addition, it reconfirms the importance of destination image as an antecedent of tourists' loyalty to a destination with the application of the four-component structure of destination image. Using the data collected from international tourists to Vietnam and applying the structural equation modelling method, this study revealed that destination image could be structured by the functional, psychological, mixed, and affective components. All of these components could significantly predict tourists' loyalty; however, the impact of the affective component was the largest. Theoretical implication for psychology-based marketing, and managerial implication for the projection and communication of Vietnam's image were discussed.
\end{abstract}

(C) 2015 Varna University of Management. All rights reserved

Keywords: destination image, cognition, affect, Vietnam, international tourists

Citation: Nghiêm-Phú, B. (2015) A confirmation of the four-component structure of destination image, and their relationships with tourists' loyalty. European Journal of Tourism Research 11, pp. 147-153

\section{Introduction}

Destination image is one of the most popular research topics in tourism. The application of destination image study can be seen in the fields of destination marketing and/or branding, and destination management, among others. Destination image is something that an individual can see, imagine or recall, and feel. Nghiêm-Phú (2014) collected the components which represent destination image in previous studies and formed an integrative definition of this construct. Accordingly, destination image is regarded as "the knowledge, impressions, prejudices, imaginations, emotional thoughts, beliefs, ideas, conceptions, attitudes, benefits, values, expectations, and interpretations that an individual holds about a destination" (Nghiêm-Phú, 2014: 40). 
A confirmation of the four-component structure of destination image, and their relationships with tourists' loyalty.

Many researchers have argued that the construction of destination image remains an issue in this field of study (e.g. Stepchenkova \& Mills, 2010). Two of the most frequently applied models of destination image structure are the multi-dimensional model (Echtner \& Ritchie, 1991, 2003), and the hierarchical model (Baloglu \& McCleary, 1999). According to Echtner and Ritchie (1991, 2003), destination image is structured by the functional or the more visible attributes, and the psychological or the more invisible attributes, also by the common and unique characteristics. In addition to the attribute-based image (cognitive), destination image is also represented by a holistic perception, and the affective impressions (Echtner \& Ritchie, 1991, 2003; Baloglu \& McCleary, 1999). The correlations among the cognitive, affective, and holistic/overall components of destination image were verified by Baloglu and McCleary (1999). Accordingly, the cognitive component significantly affects both the affective and overall ones, while the affective component significantly influences the overall perception. Later empirical efforts have validated the functional-mixed-psychological structure (Alcañiz, García \& Blas, 2009), and the coreperiphery structure (Lai \& Li, 2012) of the cognition-based component of destination image. This component may also be constructed by different activities (Prebežac \& Mikulić, 2008; Jeong, 2014), or unique characteristics (Qu, Kim \& Im, 2011). Among these approaches, activity-based cognitive image can also be considered as the expected or actual experiences that an individual may have at a destination. Unique cognitive image cannot fully represent this component if setting aside the common cognitive image (which is also constructed by the visible, invisible, and mixed visible and invisible attributes). Similarly, the core and periphery components of cognitive destination image may also be structured by the three subcomponents proposed by Echtner and Ritchie (1991, 2003). To be specific, the cognitive image component includes the attributes which can be seen (e.g. tourist attractions, infrastructures) - functional, felt but not feelings or emotions (e.g. friendliness, service quality) - psychological, and both seen and felt (e.g. safety, sanitary) - mixed.
In addition to the cognitive and affective components, Gartner (1993) incorporated the conative component into the model of destination image structure. This component reflects the future intentions of an individual, and depends on both the cognitive and affective elements. With the experienced or actual tourists in particular, their future intentions are considered as their loyalty to a destination. Zhang, Fu, Cai and Lu (2014) defined three types of loyalty: behavioral, attitudinal, and composite. Specifically, behavioral loyalty reflects a behavioral outcome (e.g. intention to recommend), while attitudinal loyalty is a psychological expression (e.g. intention to revisit). A composite loyalty is the combination of both the behavioral and the attitudinal components.

Empirical research has also confirmed the importance of destination image components with the intentions of individuals (e.g. Prayag \& Ryan, 2012). A meta-analysis conducted by Zhang, Fu, Cai and Lu (2014) provided more information about the predictive power of each image component. Accordingly, the impact of the affective component was found to be larger than that of the cognitive component, while the combination of cognitive and affective images could not generate a stable impact on tourists' loyalty. However, this analysis was based on previous studies surveying both experienced (revisit intention) and inexperienced (visit intention) tourists; thus, the impacts of these two components on actual tourists' intentions were intermingled with those on potential tourists. Moreover, the contribution of each subcomponent of cognitive image remains unknown.

Based on the existing knowledge about the structure of destination image, and its impact on tourists' future intentions, this study aims to address the following two issues. First, it attempts to reconfirm the cognitive-affective structure of the construct, with the cognitive component consists of three subcomponents of function, mixed, and psychology (Echtner \& Ritchie, 1991, 2003; Baloglu \& McCleary, 1999; Alcañiz, García \& Blas, 2009). Second, it aims to reconfirm the correlations among the components of destination image, and tourists' future intentions (Gartner, 1993; Prayag \& 
Ryan, 2012). The following sections will discuss the method and findings of this study.

\section{Study design and data collection}

Vietnam was selected as the context of this study. Located in the Southeast Asia region, Vietnam is a developing country, and tourism industry is considered as one of the engines of its economic development. In 2014, Vietnam hosted approximately 7.9 million international tourist arrivals (VNAT, 2014).

In this study, international tourists visiting Vietnam were targeted as the subjects. A structured method was adopted to achieve the research objectives. The self-administered questionnaire (which was designed for a bigger project) asked the respondents to evaluate the preselected attributes of Vietnam, and the possibility of their future intentions (i.e. loyalty). Twenty-two items to measure the cognitive component of destination image were selected from the existing literature using the context of Vietnam (e.g. Tran, Schneider, \& Gartner, 2006; Truong \& King, 2009). These items were then divided into three categories of functional attributes (13 items), mixed attributes (5 items), and psychological attributes (4 items) based on the categorization of Echtner and Ritchie (1991, 2003). Also following previous studies, a four bipolar items to measure the affective component created by Russell and Pratt (1980) was adopted. A five-point Likert-type scale was applied to measure the components of destination image. Tourists' loyalty included their intention to revisit and intention to recommend, and were evaluated through a seven-point Likert-type scale. The omnibus questionnaire was pretested on a sample of 102 international tourists in Hanoi, Vietnam in August 2013. It was shown that the respondents could respond to the questions properly; thus, no adjustment was made to the questionnaire after that.

The main survey was conducted during a period of six months (February - July 2014). The downtown area of Hanoi was selected as the study site as it has a concentration of international tourists to Hanoi, and a large amount of accommodations of many types. The recruitment of the hotels followed a purposive and snowball basis. First, the researcher contacted an alumna of a university that he has known; this alumna is currently working in a hotel in the survey site. Next, the alumna was requested to ask for help from other hotels that she has contacts with. Ultimately, five hotels agreed to take part in the survey voluntarily. Before the survey began, the staff were instructed about the purpose and method of the study. After that, they approached and collected the answers from their hotel guests in a random way. During the survey period, a total of 485 valid answers were collected, in which a sample of 367 complete responses for the image subscales were used as the basis of the analysis. Nearly $60 \%$ of the respondents were in the age of $20-29$, and nearly $23 \%$ of them were students. Male and female respondents were nearly equal $(46.9 \%$ and $50.4 \%$ respectively; $2.7 \%$ of the respondents did not report their gender). The majority of them came from a European country $(52.3 \%)$, followed by tourists from Oceania $(19.6 \%)$, Northern America (13.6\%), and Asia (9.5\%).

The analysis of the data included the following procedures. First, Cronbach's alphas were calculated using SPSS 16 to check the internal consistencies of the subscales. A subscale should have an alpha of larger than 0.70 , and the corrected item-total correlation value of each item should be 0.30 or above (Leech, Barrett \& Morgan, 2005). Next, confirmatory factor analysis and structural equation modeling were computed by Amos 21 to verify the integrative structure and correlations. The structure is validated when all factor significantly correlate to one another (Campbell \& Fiske, 1959); average variance extracted (AVE) of a factor $>0.50$, construct reliability (CR) of one factor $>0.70$, and squared correlation of two factors (SC) < their AVEs (Fornell \& Larcker, 1981). The model is accepted when the following criteria are met: $x^{2} / d f<3$, SRMR $<0.10$, RMSEA $<0.08$, GFI $>$ 0.90 , and $A G F I>0.85$, with $X^{2}=$ Chi square, $d f$ $=$ degree of freedom, SRMR = Standardized Root Mean squared Residual, RMSEA = Root Mean Square Error of Approximation, GFI = Goodness-of-Fit Index, and AGFI = Adjusted Goodness-of-Fit-Index (Schermelleh-Engel, Moosbrugger \& Müller 2003). 


\section{Findings}

The confirmation of destination image structure

The alphas of the functional, mixed, psychological, and affective subscales were $0.726,0.642,0.683$, and 0.727 respectively. To improve the internal consistencies of the cognitive subscales, several items which had low corrected item-total correlation values were removed (four functional items, two mixed items, and one psychological item). After adjusting, the alphas of the cognitive subscales were $0.730,0.724$, and 0.765 .

The confirmation analysis followed with the adjusted subscales of destination image. Five functional items which had factor loadings below 0.50 were deleted after considering the psychometric properties of the items (e.g. factor loading, error, AVE, and CR). The alpha of the remaining items only had a value of 0.659 although their corrected item-total correlations all exceeded 0.30 . The outcomes are displayed in Table 2 and Table 3 . Accordingly, all the components significantly correlated to one another with medium-large sizes of effect (Leech, Barrett \& Morgan, 2005); thus, the convergent validity criterion was met (Campbell \& Fiske, 1959). The mixed, psychological, and affective components had AVEs of close to or above the 0.50 threshold. However, the AVE of the functional component only had a value of 0.416 . In this case, the variance due to measurement error was larger than the variance captured by the component, and the validity of the items and the component is questionable (Fornell \& Larcker, 1981). Yet, the functional component's reliability met the

Table 1. Structure validation

\begin{tabular}{|c|c|c|c|c|c|c|c|}
\hline Component & Item & Mean & Loading & Error & AVE & CR & Alpha \\
\hline \multirow[t]{5}{*}{ Functional } & & & & & 0.416 & 0.739 & 0.659 \\
\hline & Architecture & 3.78 & 0.511 & 0.534 & & & \\
\hline & Accommodations & 3.87 & 0.613 & 0.330 & & & \\
\hline & Restaurants & 4.05 & 0.594 & 0.388 & & & \\
\hline & Transportation & 3.29 & 0.603 & 0.647 & & & \\
\hline \multirow[t]{4}{*}{ Mixed } & & & & & 0.526 & 0.769 & 0.724 \\
\hline & Political stability & 3.55 & 0.640 & 0.375 & & & \\
\hline & Safety, security & 3.70 & 0.749 & 0.388 & & & \\
\hline & Cleanliness & 3.15 & 0.680 & 0.526 & & & \\
\hline \multirow[t]{4}{*}{ Psychological } & & & & & 0.625 & 0.832 & 0.765 \\
\hline & People's friendliness & 4.14 & 0.790 & 0.286 & & & \\
\hline & Ways of life & 3.85 & 0.701 & 0.329 & & & \\
\hline & Service quality & 3.99 & 0.684 & 0.337 & & & \\
\hline \multirow[t]{5}{*}{ Affective } & & & & & 0.499 & 0.799 & 0.727 \\
\hline & Unpleasant/Pleasant & 4.19 & 0.686 & 0.311 & & & \\
\hline & Sleepy/Arousing & 3.95 & 0.597 & 0.394 & & & \\
\hline & Distressing/Relaxing & 3.56 & 0.613 & 0.572 & & & \\
\hline & Gloomy/Exciting & 4.17 & 0.655 & 0.359 & & & \\
\hline
\end{tabular}

Table 2. Correlations among components

\begin{tabular}{llll} 
& Mixed & Psychological & Affective \\
\hline Functional & $0.552(0.305)$ & $0.537(0.288)$ & $0.468(0.219)$ \\
Mixed & - & $0.659(0.434)$ & $0.462(0.213)$ \\
Psychological & - & $0.649(0.421)$ \\
\hline
\end{tabular}

Note: All correlations were significant at the 0.000 level. Squared values are shown in the brackets.

Table 3. Correlations confirmation result

\begin{tabular}{llll}
\hline Correlation & $\begin{array}{l}\text { Standardized } \\
\text { coefficient }\end{array}$ & Significance & Status \\
\hline Functional image $\rightarrow$ Revisit & 0.309 & 0.000 & Confirmed \\
Functional image $\rightarrow$ Recommendation & 0.298 & 0.000 & Confirmed \\
Mixed image $\rightarrow$ Revisit & -0.465 & 0.000 & Confirmed \\
Mixed image $\rightarrow$ Recommendation & -0.368 & 0.000 & Confirmed \\
Psychological image $\rightarrow$ Revisit & 0.240 & 0.028 & Confirmed \\
Psychological image $\rightarrow$ Recommendation & 0.265 & 0.009 & Confirmed \\
Affective image $\rightarrow$ Revisit & 0.541 & 0.000 & Confirmed \\
Affective image $\rightarrow$ Recommendation & 0.563 & 0.000 & Confirmed \\
\hline
\end{tabular}


standard level of 0.70 , and CR is less conservative than AVE (Fornell \& Larcker, 1981). The structure also met the discriminant validity criterion because all the SCs were smaller than their AVEs (Table 3). The overall fit of the model was represented by the following indices: $x^{2} / d f=2.750(<3.0)$, SRMR $=$ $0.056(<0.10)$, RMSEA $=0.069(<0.08), \mathrm{GFI}=$ $0.927(>0.90)$, and $\mathrm{AGFI}=0.893(>0.85)$. Consequently, the four component structure of destination image could be accepted.

\section{The confirmation of the relationships between destination image components and tourists' future intentions}

The correlations between the four components of destination image and tourists' intentions were confirmed using the structural equation modeling method. The fit indices of the model included $\mathrm{X}^{2} / d f=2.984(<3.0)$, SRMR $=0.056$ $(<0.10)$, RMSEA $=0.074(<0.80), \mathrm{GFI}=0.915$ $(>0.90)$, and AGFI $=0.874 \quad(>0.85)$. Consequently, the model was accepted. The directions, magnitudes, and significances of the correlations are displayed in Table 4. Accordingly, four components of destination image affected both tourists' intentions to revisit and to recommend. All significant effects were positive, except those of the mixed cognitive image.

\section{Discussion and conclusion}

The findings of this study confirmed the theory of the multidimensional structure of destination image, and the effect that destination image can generate on tourists' loyalty to the destination. It was found in this study that affective image is the component had the strongest effect on tourists' loyalty, followed by the mixed, functional, and psychological components. This outcome is consistent with the observation found in Zhang, Fu, Cai and Lu (2014) regarding the importance of the affective component. Affective image was also found to have the largest effect on the formation of destination image by San Martin and del Bosque (2008) when they examined the perceptions of the actual tourists to Spain. The outcome of this study, however, differed from the finding of Alcañiz, García and Blas (2009). Testing on a sample of tourists in a resort area in Spain, Alcañiz, García and Blas (2009) found that functional image only affected intention to revisit, psychological image only influenced intention to recommend, while mixed image didn't affect both intentions. In the case of international tourists to Vietnam, all image components affected tourists' intentions.

This outcome suggests two implications. First, the importance of the affective component of destination image should be recognized, especially in case of the actual tourists. This understanding is complemented by the theory of psychology-based marketing. According to Maddock and Fulton (1996), consumer decisions are mostly relied on their emotion, not their cognition. In human brain, emotions and feelings are processed by the right side and the related information will be stored in the long term. On the other hand, the cognitive thinking and reasoning are administered by the left side and its information will be kept in the short term. Consumers' initial and final decisions are made by the right side (Maddock \& Fulton, 1996). In other words, when the information are presented in the affective forms (i.e. emotions, feelings), they may be kept longer, and they can perform their effects more effectively. With a destination, its affective image is formed under the influence of the cognitive attributes (Baloglu \& McCleary, 1999). Therefore, the projection and communication of positive cognitive images is really important because they can generate positive emotions/feelings, and can be preserved in tourists' long-term memories. From the marketing perspective, the application of psychological knowledge will result in longer, more stable, and more effective effects. Current actual tourists are not only future potential visitors but also potential informants. They are an important source of organic information to their friends and family and should be used in an effective way (Gartner, 1993).

Second, the effect of each cognitive image component is context-based. In other words, whereas feelings can be measured by the same scale in many settings, cognitive attributes must be specifically and suitably selected for a particular destination. Consequently, each destination should carefully examine its own image, and select its own focuses in terms of what to create and 
what to communicate to win over tourists' loyalty. With Vietnam tourism in particular, the most important tangible attributes are architecture, accommodations, and restaurants. These basic characteristics should be emphasized when communicating the image of the country to its tourists, especially the actual ones. However, some problems with the transportation and environmental conditions of a developing country like Vietnam should be addressed. Particularly, transportation was given a mean value of only 3.29 out of 5 points (higher than that of cleanliness to be 3.15). In Vietnam, there are too many private transportation vehicles while the public transportation system is underdeveloped. Moreover, many drivers don't follow traffic rules and respect street walkers (Kiều Giang, 2014). This particular problem needs time to negotiate. One of the methods is to educate the local residents to improve their trafficparticipating attitude, and to invest in the public transportation system together with the reduction of private vehicle use. Education is also a key to improve some less tangible attributes of the country (i.e. cleanliness). In addition, the communication of the country's image should not forget other less tangible and intangible attributes, for example, safety, security, local ways of life, and people's friendliness.

This study, however, could not avoid some limits. First, the responses $(n=367)$ were collected from a modest number of hotels, and were small compared to the total international tourist arrivals to Vietnam in general (approximately 7.9 million in 2014) and to Hanoi in particular (approximately 3 million in 2014). Second, the instrument was only written in English. Thus, those tourists who could not use English were eliminated from the survey. Consequently, the result of this study cannot be generalized to the whole international tourist population to Vietnam. To address this issue, future studies may replicate the current effort in a larger scale, and use the instruments written in different languages. Third, the confirmation analysis showed that the psychometric properties of the functional component were weak. Therefore, further efforts should follow to create a more reliable scale to measure the cognitive image of Vietnam as a tourism destination, especially the functional attributes.

In conclusion, this study has confirmed that destination image was structured by the four components of function, mixed, psychology, and affect. These components were found to have significant effects on actual international tourists' loyalty to the destination, with the effect of the affective element to be the largest. Consequently, this report advocates a psychological approach when projecting and communicating the image of a destination, especially to the actual tourist population. The affective image of a destination should be emphasized, and the projection of positive cognitive image can help enhance this procedure. The impressions in the form of emotional memories are kept in the long-term; therefore, their impacts can last longer and perform more effectively.

\section{References}

Alcañiz, E. B., García, I. S. \& Blas, S. S. (2009). The functional-psychological continuum in the cognitive image of a destination: A confirmatory analysis. Tourism Management, 30, 715-723.

Baloglu, S. \& McCleary, K. W. (1999). A model of destination image formation. Annals of Tourism Research, 26 (4), 868-897.

Báo điện tử Đảng Cộng sản Việt Nam [Kiều Giang]. (2014, October 09). Giao thông công cộng ở Hà Nội qua lăng kính một chuyên gia Nhật Bản [Public transportation in Hanoi from the perspective of a Japanese expert]. Retrieved December 24, 2014, from http://dangcongsan.vn/cpv/Modules/Ne ws/NewsDetail.aspx?co_id=30315\&cn id $=679051$

Campbell, D. T. \& Fiske, D. W. (1959). Convergent and discriminant validation by the multitrait-multimethod matrix. Psychological Bulletin, 56 (2), 81-105.

Echtner, C. M. \& Ritchie, J. R. (1991). The meaning and measurement of destination image. Journal of Tourism Studies, 2 (2), 2-12.

Echtner, C. M. \& Ritchie, J. R. (2003). The meaning and measurement of destination image. Journal of Tourism Studies, 14 (1), 37-48. 
Fornell, C. \& Larcker, D. F. (1981). Evaluating structural equation models with unobservable variables and measurement error. Journal of Marketing Research, 18 (1), 39-50.

Gartner, W. (1993). Image formation process. Journal of Travel and Tourism Marketing, 2 (2/3), 191-215.

Jeong, C. (2014). Marine tourist motivations comparing push and pull factors. Journal of Quality Assurance in Hospitality \& Tourism, 15 (3), 294-309.

Lai, K. \& Li, Y. (2012). Core-periphery structure of destination image - Concept, evidence and implication. Annals of Tourism Research, 39 (3), 1359-1379.

Leech, N. L., Barrett, K. C. \& Morgan, G. A. (2005). SPSS for intermediate statistics: Use and interpretation (2 ed.). Mahwah, NJ: Lawrence Erlbaum Associates.

Maddock, R. C. \& Fulton, R. L. (1996). Marketing to the mind - Right brain strategies for advertising and marketing. Westport, CT: Quorum Books.

Nghiêm-Phú, B. (2014). A review of destination image studies from 2008 to 2012. European Journal of Tourism Research, 8, 35-65.

Prayag, G. \& Ryan, C. (2012). Antecedents of tourists' loyalty to Mauritius: The role and influence of destination image, place attachment, personal involvement, and satisfaction. Journal of Travel Research, 51 (3), 342-356.

Prebežac, D. \& Mikulić, J. (2008). Destination image and key drivers of perceived destination attractiveness. TRŽıŠTE, 20 (2), 163-178.

Qu, H., Kim, L. H. \& Im, H. H. (2011). A model of destination branding: Integrating the concepts of the branding and destination image. Tourism Management, 32, 465-476.
Russell, J. A. \& Pratt, G. (1980). A description of the affective quality attributed to environments. Journal of Personality and Social Psychology, 38 (2), 311322.

San Martin, H. \& del Bosque, I. A. (2008). Exploring the cognitive-affective nature of destination image and the role of psychological factors in its formation. Tourism Management, 29, 263-277.

Schermelleh-Engel, K., Moosbrugger, H. \& Müller, H. (2003). Evaluating the fit of structural equation models: Tests of significance and descriptive goodnessof-fit measures. Methods of Psychological Research Online, 8 (2), 23-74.

Stepchenkova, S. \& Mills, J. E. (2010). Destination image: A meta-analysis of 2000-2007 research. Journal of Hospitality Marketing \& Management, 19, 575-609.

Tran, T.-H., Schneider, I. E. \& Gartner, W. C. (2006). Image of Vietnam held by US tourists: Initial inquiry. Asia Pacific Journal of Tourism Research, 11 (2), 147-159.

Truong, T.-H. \& King, B. (2009). An evaluation of satisfaction levels among Chinese tourists in Vietnam. International Journal of Tourism Research, 11, 521535.

Vietnam National Administration of Tourism [VNAT]. (2014, December 31). Khách quốc tế đến Việt Nam tháng 12 và 12 tháng năm 2014 [International tourists to Vietnam in December and 2014]. Retrieved January 26, 2015, from Vietnam National Administration of Tourism:

http://vietnamtourism.gov.vn/index.php/ items/16397

Zhang, H., Fu, X., Cai, L. A. \& Lu, L. (2014). Destination image and tourist loyalty: A meta-analysis. Tourism Management, 40, 213-223. 